of the variation of the seconds' pendulum with latitude was quite trustworthy enough (not to say correct enough) to furnish the geographical difference between London and Paris lengths. Yet as a fact the pendulum never was so appealed to. Yet to this day it is still not uncommonly taught that the pendulum is the proper natural standard of reference. In 1816 of course such was the nearly universal dogma.

I say "never," but perhaps one or other of the above observers may be adduced to confute me.

Collingwood, July in

\section{Faure's Secondary Battery}

In your issue of last week you gave an account of the soirée beld at King's College, London, on the evening of July 2, and in this account it is stated that "the great event of the evening was the exhibition for the first time in England of M. Faure's secondary battery."

At the soirées given by the Mayor of Nottingham on the evenings of June 30 and July 3 in connection with the opening of the College by H.R.H. Prince Leopold, I had the pleasure of exhibiting to large audiences one of M. Faure's new batteries. Sheets of lead were bent up into the form of shallow trays, one foot square and one inch deep; in each of these was placed a layer of red lead, then a layer of flannel, then a layer of red lead, and lastly another lead plate. These trays to the number of six were then piled one above the other, after being filled with dilute acid. The cells being connected in series, were polarised by a 10-cell battery of Grove's cells, and after twenty minutes' charging, had taken up a very large quantity of electricity. At a short lecture given during the evening the charged Faure battery was connected with a Gramme machine, and drove it round with considerable velocity for some minutes. After thus employing part of the charge the remainder was used for heating several inches of platinum wire, and for driving for a few seconds a simple form of magneto-electric engine. These experiments amply convinced those present of the practical character of $\mathrm{M}$. Faure's invention. As I have not had the opportunity of examining one of the original batteries of the inventor, I was obliged to make up this experimental form. It is however a convenient form for lecture-room demonstration, as it permits the structure of the battery to be exhibited to an audience. The enormous superiority of M. Faure's cell over the old form of Planté cell is evident at once on experimenting with it. J. A. FLEMING

The University College, Nottingham, July io

\section{Earthquake in Van}

SINCE my former letter I have had an opportunity of visiting the region most affected by the earthquake of May 30 , and have obtained some further particulars about it. Its greatest severity seems to have been felt at the Armenian village of Teghourt, lying at the foot of the Nimroud Dagh, at a distance, judging by eye, of not more than four miles from the edge of the crater. This village has been almost entirely destroyed, with the loss of ninetythree lives. By the same shock about 200 houses were thrown down or more or less damaged in the aggregation of hamlets named Akhlat, some six or seven miles further distant from the Nimroud Dagh. Here however happily only two lives were lost and a few persons were injured. On June 9, in the evening, a second shock took place of less violence, which partially damaged a third village, Sipratzor, lying between the other two. As far as I was able to learn these villages were the only localities in which buildings were actually thrown down, though cracks were caused in walls, \&c., in other places. The three villages are all in the direct line between the two great extinct volcanoes of the Nimroud Dagh and Sipan Dagh, which fact leads to the conjecture that there may be a line of least resistance joining the two mountains. All three villages, however, are nearer to Nimroud than to Sipan. The greater severity of the shock at Teghourt, the nearest village to Nimroud, may have been due to the latter having been the centre of the disturbance, but it may also have been caused by the fact that the village is built directly upon the solid rock of an ancient lava-bed. The only observation I was able to obtain of the direction of the earthquake wave was communicated to me at a village lying due east of the Nimroud Dagh. Here it was said that the wave came from the south, which would look as if the centre of disturbance were in the Central Kurdistan mountains, not in Nimroud; but one doubtful observation is of course not enough to establish such a point.
Whilst in the neighbourhood I took the opportunity of visiting the Nimroud Dagh. The mountain rises in a very gentle slope, so that it is possible to ride the whole way up and into the crater. The edge of the crater, where we crossed it, is 28 ro feet above the Lake of Van by aneroid and about six miles distant from it ; some parts of the walls however rise 500 feet or so higher, the most elevated points being to the north and south. The crater is a vast, nearly perfectly circular, hollow, between four and five miles across, the floor of which is an irregular flat dome, partly covered with herbage and partly with dwarf birch and beech and a creeping yew. Among the undulations of the dome, and especially in the depressed ring between the dome and the walls of the crater, are situated some six or seven tarns. One of these, on the margin of which we stopped to rest, is fed by hot springs, which bubble up at numerous points near its edge. I had no thermometer to ascertain the temperature of the water, but I found that one spring, which rose in a small basin almost cut off from the rest of the lake, was just about as hot as I could bear to keep my hand in. This tarn is 880 feet lower than the edge of the crater where we crossed it, this being the lowest point in the whole circuit. I saw no sign of vaporous exhalation, although local tradition has it that the mountain was active not more than four centuries ago; but time did not permit me to explore the whole of the great interior space.

Van, Turkey-in-Asia, June 20

\section{Meteors}

Several splendid meteors having lately been visible, the following observations may be worthy of note in NATURE. I may add that the most brilliant meteor was the one recorded in your columns (vol. xxiv. p. 189).

June 24 , Ioh. $28 \mathrm{~m}$., a very large bright orange-coloured meteor equal to Jupiter appeared near Vega.

At IIh. 29m. a deep orange-coloured meteor, larger and brighter, than Jupiter, crossed the extremity of the comet's tail. It left a short bright streak.

June 25 , 10h. 52m, a yellowish-white meteor, as bright as Vega, appeared near $\zeta$ Cygni.

At I $2 \mathrm{~b}, 4 \mathrm{~m}$. a white meteor, as bright as Jupiter, appeared just south of $x$ Draconis, and after pursuing a wavy path, disappeared near $\gamma$ Ursæ Majoris. It left a short streak.

July 3, Ioh. $23 \mathrm{~m}$. a yellow meteor, nearly as bright as Jupiter, appeared just east of Polaris, travelled slowly in a wavy path, and disappeared north of $\boldsymbol{\beta}$ Cassiopei.

It will be observed that three out of these five meteors appeared in that part of the sky occupied by the comet, and also that two of them pursued wavy or zig-zag paths. B. J. HopkINS

$$
\text { 79, Marlborough Road, Dalston, E., July } 5
$$

\section{The W-Pattern of Paddles}

In your impression of the 2nd ult. allusion is made to the origin of the $W$ pattern which occurs upon paddles from the Solomon Isles. Without illustration it is difficult to understand the transitions which have taken place, but with the objects before you their history is easily read. I therefore inclose sketches; they are all from the same locality. In Fig. I it is seen that the swell of the blade of the paddle has suggested the idea of a fish's body, and accordingly the head with the mouth and eyes of a fish have been carved in their proper place. In Fig. 2 the same occurs, except that the blade is bent, probably to adapt the paddle to steering purposes, or for some other object. These two specimens represent the head of a fish in its realistic form. The progress of ornamentation is from realism to conventionalism. By comparing Fig. 3 with the foregoing it is easily seen that the $W$ represents the mouth and sides of a fish's head reduced to straight lines, the eyes having disappeared. In all the specimens in my possession its position is always that in which the true fish's head occurs in the realistic specimens. In Fig. 4 a further change has taken place, the mouth is omitted, and the sides of the head have been brought together in a point, thus forming a simple triangle. Possibly the idea of a fish's head may have been altogether lost in this stage of the ornament, but in the next example, Fig. 5, the idea revives again, as so frequently happens in like cases, without recurring to the original model. Two eyes are seen to be inserted in the place where one occurred in the realistic specimens, the mouth still being deficient.

There can be little doubt, I think, that this interpretation 